\title{
Renaturing a microclimate: the impact of greening a neighbourhood on indoor thermal comfort during a heatwave in Manchester, UK
}

\author{
Mohammad Taleghani ${ }^{* 1}$, Alex Marshall, Richard Fitton, William Swan \\ University of Salford, Manchester, UK
}

\begin{abstract}
Higher air temperatures in large cities like Manchester, UK, reduce human thermal comfort. In this paper, the impact of land cover on microclimate, and consequently on indoor thermal comfort is studied. Through different stages, field measurements and computer modelling were carried out for a heat wave episode in summer 2017 in Manchester: First, the urban heat island (UHI) was measured between the city centre of Manchester and the campus of the University of Salford (between May to October 2017). Maximum detected UHI was $2.3^{\circ} \mathrm{C}$ at $4: 00$, during the hottest day of the summer.

Parallel measurements within the university campus showed that the park was $0.9^{\circ} \mathrm{C}$ cooler than the paved areas (maximum cooling effect was $3.6^{\circ} \mathrm{C}$ at $14: 45$ ).

Finally, the impact of the current land cover of the campus, and a greener land cover (as a renaturing scenario) with more planted trees on indoor thermal comfort of a house within the campus was studied. It was found that by adding $17 \%$ more trees to the campus, indoor thermal comfort was improved by $20.8 \%$ during the hottest day of 2017 in Manchester. These showed that renaturing cities could be a solution for future warmer climates.
\end{abstract}

\section{Keywords}

UHI, heat wave, land cover, microclimate, neighbourhood greening, indoor thermal comfort

\footnotetext{
${ }^{1}$ Corresponding author: Mohammad Taleghani Email addresses:

m.taleghani@salford.ac.uk (Mohammad Taleghani); A.S.Marshall1@salford.ac.uk (Alex Marshall); R.Fitton@salford.ac.uk (Richard Fitton); W.C.Swan@salford.ac.uk (William Swan).
} 


\section{Introduction}

The temperature difference between cities and corresponding suburbs is called the Urban Heat Island (UHI) effect [1]. UHIs form because a) cities generate anthropogenic heat and cannot release it to the sky as easy as suburbs, b) urban surfaces in cities are dark and absorb solar energy, and c) cities have less vegetation and permeable surfaces [2-4]. The higher air temperatures affect energy consumption [5, 6] and people's health [7-9] in cities.

Manchester is located in North-West of the UK, with a temperate climate [10]. The UK Met Office [11] predicts that average air temperature in summer could rise up to $5^{\circ} \mathrm{C}$ by 2080 in this area of the UK (high emission scenario, compared to the 1961-1990 baseline). In 2009, UK Government decided to reduce $\mathrm{CO}_{2}$ levels by $80 \%$ by 2050 (compared to 2005 level) [12]. As a result, Manchester City Council is committed to reduce its emissions by $41 \%$ by 2020 . Skelhorn et al. [13] studied the seasonal intensity of UHI in Manchester. They found that the $\mathrm{UHI}$ in summer ranges between 0.5 and $5.0^{\circ} \mathrm{C}$. Likewise, Levermore et al. [14] quantified the $\mathrm{UHI}$ in Manchester, between Hulme (assumed as the city centre) and Manchester Airport (assumed as the rural site), in the period of 1996- 2011. They could show that the UHI in Manchester will add $2.4^{\circ} \mathrm{C}$ to the average city temperature, on top of the predicted global warming.

The increase of air temperatures in large cities like Manchester will lead to the use of air conditioning systems [15], thus higher electricity demand and higher green house gas emissions. A passive strategy to mitigate heat in cities is to alter the land cover in a way that less solar radiation could be absorbed [16-19]. Water bodies, high albedo materials, and vegetation can mitigate ambient air temperature to improve energy efficiency and thermal comfort [20-23]. A study in Singapore showed that the air temperatures within 10 parks were $8-12{ }^{\circ} \mathrm{C}$ cooler than the city [24]. Coccolo [25] also studied the impact of vegetation on two university campuses in different climates; EPFL in Switzerland, and SISD in United Arab Emirates. The study showed the importance of open spaces for providing comfortable microclimates. In addition, it was shown that indoor energy demand and comfort are strongly correlated to outdoor microclimate. Furthermore, several scholars have reported the contribution of vegetation on the roof level (as green roof) in reducing the ambient air temperature in cities [26, 27]. However, less studies have coupled outdoor and indoor thermal environmets in a way to explore the impact of changing the neighbourhood land cover and greenness on indoor thermal comfort.

In this paper, four study phases were carried out to understand the impact of land cover on indoor thermal comfort. First, we measured the UHI in Manchester- University of Salford. Then, the impact of land cover on local microclimate within the campus of University of Salford was studied. As the third phase, a greener land cover (with additional trees) was simulated for the campus. At the end, the impact of this land cover change on indoor thermal comfort was studied. Improving the microclimate within the campus of the University of Salford will not only impact the educational spaces, but also the residential buildings in the campus that are susceptible to overheating in the future. 


\section{Methodology}

\subsection{Phase 1: Measurements of local microclimates and the UHI in summer 2017}

Micrometeorological factors (air temperature, wind speed, wind direction, relative humidity, and solar radiation) were recorded in the campus of the University of Salford. Likewise, air temperature in the city centre of Manchester was recorded. The distance between the two measurement sites was $2.9 \mathrm{~km}$ (Figure 1). The aim was to capture the temperature difference between the campus and the city centre (urban heat island in Manchester). The data were recorded from May to October 2017, with the interval of 15 minutes.

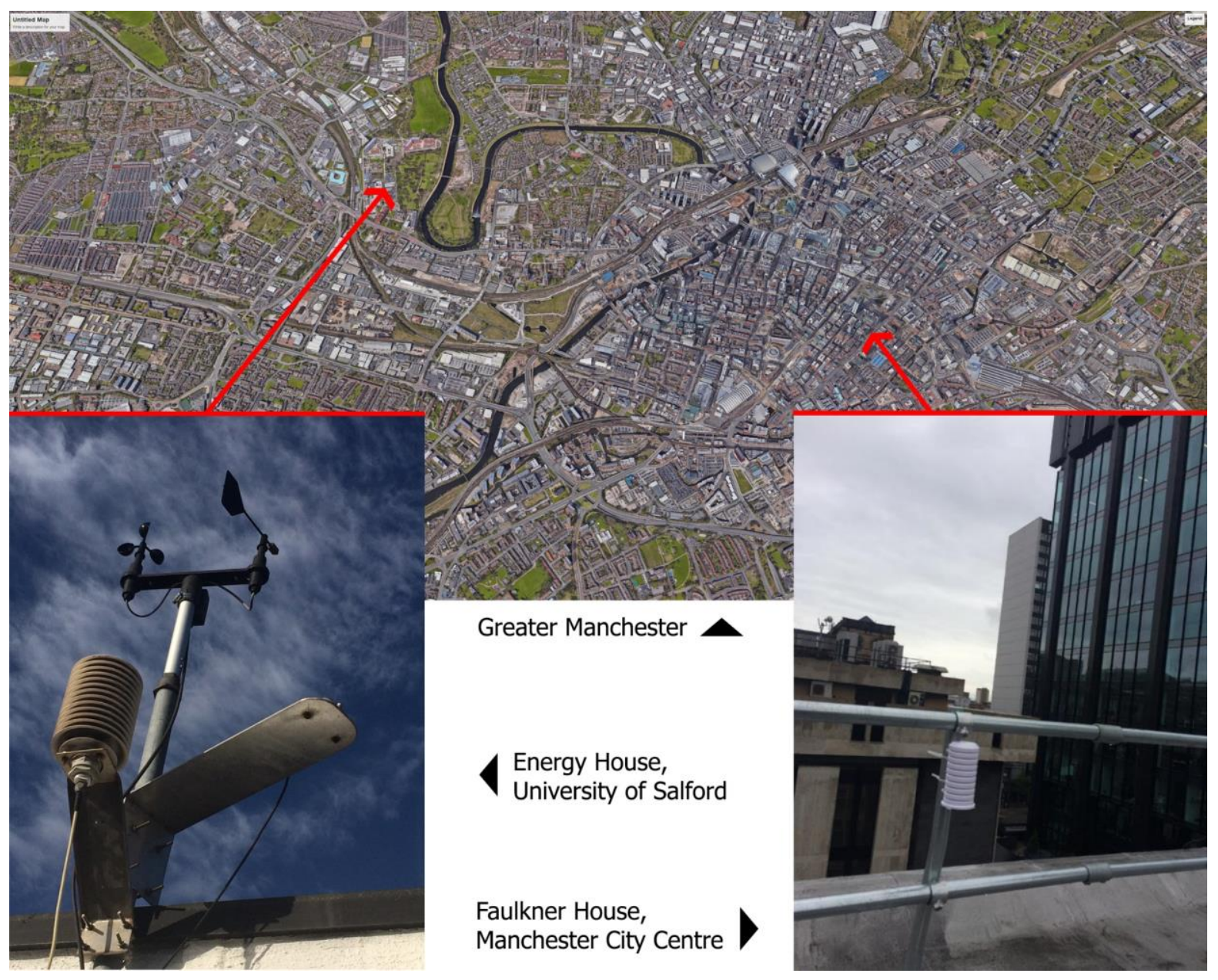

Figure 1: Top: The aerial view of Manchester (image from Google Maps). Left: The weather station on the roof of the Energy House building at the campus of the University of Salford. Right: HOBO data logger installed on the roof of the Faulkner House in Manchester city centre.

The weather station in the campus of the University of Salford used an MP100A sensor [28]. This weather station is installed on the roof of the Energy House building of the University. For the city centre, a HOBO MX2305 was used [29]. This data logger was mounted on the roof of one of the Manchester city council's building, called Faulkner House. To avoid direct solar radiation and rain, the data loggers were protected by a TFA Dostmann Weather 
Protection Cage. This building is located at the heart of the city centre, and for the calculation of UHI we assumed it as the city centre. The specification of the sensors are described in Table 1.

Table 1: Specification of the equipment used in the study.

\begin{tabular}{|l|l|l|}
\hline Location & Sensor & Accuracy \\
\hline University of Salford & Air Temp. \& Relative Humidity: & $\begin{array}{l} \pm 0.5^{\circ} \mathrm{C} \text { (temp.), } \pm 1 \% \\
(\mathrm{RH})\end{array}$ \\
\cline { 2 - 3 } & MP100A & $\begin{array}{l} \pm 0.5 \mathrm{~m} / \mathrm{s} \text { (speed), } \pm 5^{\circ} \\
\text { (direction) }\end{array}$ \\
\cline { 2 - 3 } & $\begin{array}{l}\text { Wind speed and direction: } \\
\text { 03002-L Wind Sentry Set }\end{array}$ & $\pm 0.015 \mathrm{in} \mathrm{Hg}$ \\
\cline { 2 - 3 } & Barometric pressure sensor: & \\
& RPT 410 & $\pm 2.0^{\circ} \mathrm{C}$ \\
\cline { 2 - 3 } & $\begin{array}{l}\text { Thermal camera: } \\
\text { FLIR C2 }\end{array}$ & $\pm 0.2{ }^{\circ} \mathrm{C}$ \\
\hline Manchester city centre & Air temp.: & \\
& HOBO MX2305 & \\
\hline
\end{tabular}

\subsection{Phase 2: Micrometeorological simulations and measurements within the campus}

ENVI-met (v4.3 Science) was used to model the microclimate of the campus [30]. ENVI-met is a computational fluid dynamic (CFD) software. The model handles turbulence by solving the non-hydrostatic incompressible Reynolds-Averaged Navier-Stokes equations [31]:

$\frac{\partial u}{\partial t}+u_{i} \frac{\partial u}{\partial x_{i}}=-\frac{\partial p^{\prime}}{\partial x}+K_{m}\left(\frac{\partial^{2} u}{\partial x_{i}^{2}}\right)+f\left(v-v_{g}\right)-S_{u}$

$\frac{\partial v}{\partial t}+u_{i} \frac{\partial v}{\partial x_{i}}=-\frac{\partial p^{\prime}}{\partial y}+K_{m}\left(\frac{\partial^{2} v}{\partial x_{i}^{2}}\right)-f\left(u-u_{g}\right)-S_{v}$

$\frac{\partial w}{\partial t}+u_{i} \frac{\partial w}{\partial x_{i}}=-\frac{\partial p^{\prime}}{\partial z}+K_{m}\left(\frac{\partial^{2} w}{\partial x_{i}^{2}}\right)+g \frac{\theta(z)}{\theta_{\text {ref }}(z)}-S_{w}$

$\frac{\partial u}{\partial x}+\frac{\partial v}{\partial y}+\frac{\partial w}{\partial z}=0$

where, $x, y$, and $z$ directions are presented by $u, v$ and $w$ for the wind; $f\left(=10^{4}\right.$ per sec) is the Coriolis parameter; $\rho$ is the local pressure perturbation; $\theta$ is the potential temperature at level z. Furthermore, as we used vegetation in our simulations, the local source/sink terms of $S_{u}, S_{v}$ and $S_{w}$ describe the loss of wind speed due to drag forces around vegetation [32]. Mean wind speed in ENVI-met is also calculated by $\sqrt{u^{2}+v^{2}+w^{2}}$. Moreover, as we mostly discussed air temperature in this paper, it is calculated by advective diffusion equation:

$\frac{\partial \theta}{\partial t}+u_{i} \frac{\partial \theta}{\partial x_{i}}=K_{h}\left(\frac{\partial^{2} \theta}{\partial x_{i}^{2}}\right)+Q_{h}$ 
where $K_{h}$ is the heat diffusivity.

Local turbulence $(E)$ and dissipation rate $(\varepsilon)$ to calculate turbulence near facades are solved by:

$\frac{\partial E}{\partial t}+u_{i} \frac{\partial E}{\partial x_{i}}=K_{E}\left(\frac{\partial^{2} E}{\partial x_{i}^{2}}\right)+\operatorname{Pr}-T h+Q_{E}-\varepsilon$

$\frac{\partial \varepsilon}{\partial t}+u_{i} \frac{\partial \varepsilon}{\partial x_{i}}=K_{\varepsilon}\left(\frac{\partial^{2} \varepsilon}{\partial x_{i}^{2}}\right)+c_{1} \frac{\varepsilon}{E} \operatorname{Pr}-c_{3} \frac{\varepsilon}{E} T h-c_{2} \frac{\varepsilon^{2}}{E}+Q_{E}$

where $\mathrm{K}_{\mathrm{E}}$ and $\mathrm{K}_{\varepsilon}$ here are referred to diffusivity coefficients, Pr represents mechanical production turbulent energy; Th is Buoyancy production of turbulent energy; $c_{1}, c_{2}, c_{3}$ are from [33]; and finally $Q_{E}$ and $Q_{\varepsilon}$ are local turbulent production and dissipation due to vegetation, respectively [34].

Weather data (such as air temperature, wind speed and direction, relative humidity), and physical geometry of the simulation domain (like geographical location of the simulation domain, building and urban geometries, surface properties, and spatial resolution of domain cells) are the main inputs for ENVI-met. Among the outputs, air temperature, wind speed, mean radiant temperature, and relative humidity are the ones that are mostly used for thermal comfort calculations.

ENVI-met offers three different kinds of boundary conditions: open, forced, and cyclic. In these simulations, open lateral boundary conditions was used; which means that the micrometeorological "values of the next grid point close to the border are copied to the border for each time step" of the simulation period [30]. The input data to build up the boundary conditions include: the geographical coordination of the site, date of the simulation, period (in hours); wind speed; roughness length, air temperature, relative and specific humidity.

The required weather data for the simulations were taken from Phase 1. Table 2 shows the input weather data used for the simulations. The geometrical model of the campus was built based on Google Maps. The domain covered an area of $480 \times 480 \times 80$ meters.

Table 2: Conditions used in the ENVI-met simulations.

\begin{tabular}{|l|l|}
\hline Location & Salford, Manchester, UK \\
\hline Domain area $(\mathrm{x}, \mathrm{y}, \mathrm{z})$ & $480 \mathrm{~m} \times 480 \mathrm{~m} \times 80 \mathrm{~m}$ \\
\hline Simulation day and period & $19.06 .2017,24$ hours \\
\hline Simulation start time & $04: 00 \mathrm{am}$ \\
\hline Initial air temperature & $16.9^{\circ} \mathrm{C}$ \\
\hline Initial wind speed and direction & $1.0 \mathrm{~m} / \mathrm{s}, 340 \mathrm{deg}(\mathrm{N}-\mathrm{NW})$ \\
\hline Initial relative humidity & $75 \%$ \\
\hline
\end{tabular}


A parallel measurement campaign was carried out within the campus of the University of Salford. Two HOBO MX2305 data loggers measured the air temperature within the Peel Park (University park) and a parking lot in front of the Energy House (Figure 2). As a shield for the HOBO data loggers, TFA weather protective casing was used. The distance between these two locations is $74 \mathrm{~m}$. Similar to the other field measurement, data were measured every 15 minutes, and from May to October 2017. In addition, a FLIR thermal camera was used to take thermal photos. The thermal photos were taken around 14:00h, on $11^{\text {th }}$ of September 2017. For post processing of the thermal photos, FLIR Tools v.5 was used [35]. This software makes it possible to extract surface temperatures of each point in thermal photos. The aim of this second measurement, and the thermal photos were to understand the thermal conditions within different locations of the campus.
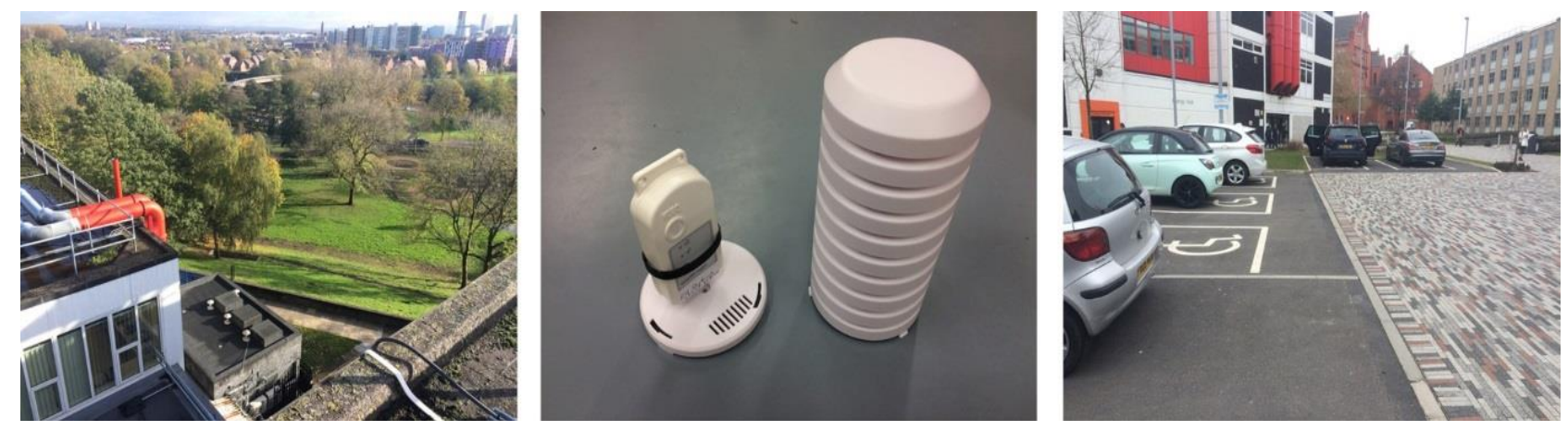

Figure 2: Peel Park (left); HOBO data logger and TFA protective shield (middle); and the parking lot (right).

\subsection{Phase 3: Study the impact of additional trees (renaturing the campus) on the microclimate}

In this phase, the land cover file of the previous ENVI-met simulation was changed (Figure 3). Additional trees were placed on the grass areas within the domain (where there is potential to plant trees). The additional trees were deciduous with distinct crown layer. The albedo of the trees were 0.2 with $30 \%$ transmition. In total, this scenario added $17 \%$ more trees to the domain (from $21 \%$ in the currect land cover to $38 \%$ in the hypothetical greener model). Similar to the simulation done in Phase 2, the weather data of the same day $\left(19^{\text {th }}\right.$ of June 2017) was used for the new simulation. 

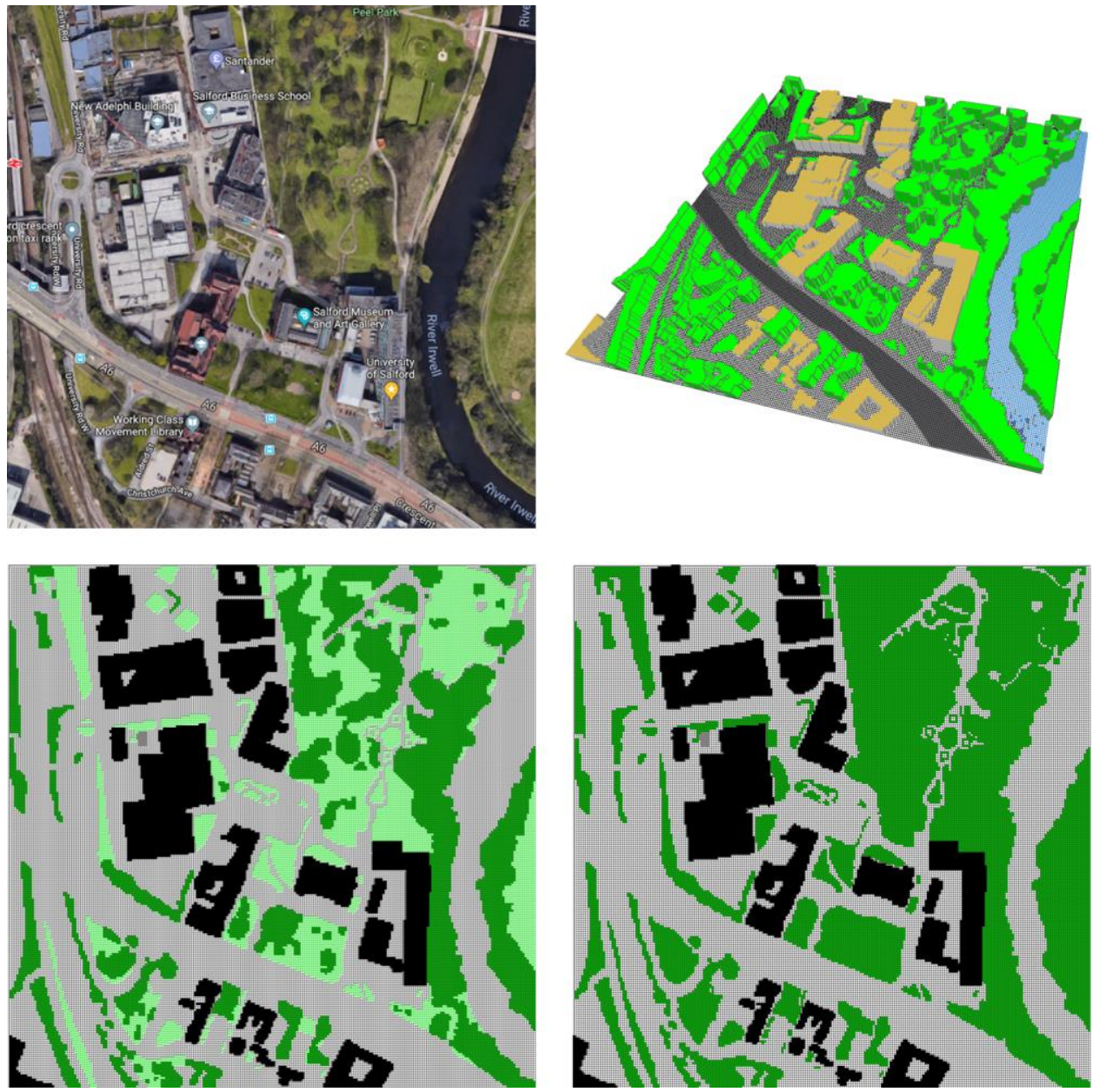

Figure 3: Top-left: The simulated domain as part of the campus of the University of Salford; Top-right: the 3D model of the domain; Bottom-left: the ENVI-met domain based on the current land cover; Bottom-right: the domain with additional trees on grass areas.

The first aim of this phase was to explore the impact of the additional trees on the microclimate of the campus. Furthermore, this phase provided a new local weather data under the additional trees scenario. This new weather data along with the one taken from Phase 2 (from the simulation of the current land cover of the campus) provided 2 weather datasets for indoor thermal conditions modelling. These datasets include hourly air temperature, relative humidity, wind speed and wind direction.

\subsection{Phase 4: Indoor thermal conditions modelling}

The Energy House is a single family house built within a climate controlled chamber (Figure 4 left and middle), in the University of Salford (for a full description of the House please see $[36,37])$. This house represents 21 percent of dwellings in the UK. In this research, we used DesignBuilder to simulate indoor thermal conditions [38]. DesignBuilder uses EnergyPlus [39] for whole building energy simulation. The DesignBuilder model of the Energy House was used for this phase of the study (Figure 4 right). 
The DesignBuilder model created in [40] was calibrated to a high degree of accuracy. This process of calibration involved the use of a number of in-situ test methodologies to characterise the thermal performance of the building, including heat flux density measurements, air permeability measurements and measurements of whole house aggregate heat loss.

Heat flux density measurements were carried out in the Energy House under steady state conditions; this allowed the calculation of $U$-value for different building elements of the dwelling, including external walls, ceilings, floors, doors and windows. Due to the controlled nature of the facility and by using the guidance set out in ISO 9869-1:2014 [41], an accurate measurement of U-values was obtained.

Air permeability was measured using a blower door test, by pressurising and depressurising the building at a fixed pressure and quantifying the flow of air required to maintain that pressure. This test was carried out using the technical standard provided in [42].

An electric co-heating test was also performed to evaluate the whole house aggregate heat loss, quantified using the heat transfer coefficient (HTC). The HTC is a measure of the global heat loss from a building's thermal envelope, including through fabric and background ventilation. This test involved artificially heating the entire building to maintain a temperature difference across the thermal envelope of the building. The HTC could then be calculated using the steady power input required to maintain that temperature difference. The electric co-heating test was carried out to the recommended methodology of [43].

DesignBuilder assigns presumed characteristics and building and building element level, giving an approximate behaviour of the building. These characteristics were replaced with those physically measured in the Energy House - both U-values and air permeability. A test on the DesignBuilder model was carried out to evaluate the theoretical HTC both before and after the calibration process was applied. Before calibration, an $18 \%$ difference was found between the measured and theoretical HTC; after calibrating the model, this difference was reduced to $2 \%$. The calibrated model can therefore be considered as a much better representation of the true behaviour of the building accurate prediction tool for building energy performance.

Assumptions in the model were:

- Construction as follows: solid walls $(222.5 \mathrm{~mm}$ brick) with dense plaster $(13 \mathrm{~mm})$; carpeted suspended timber floors $(20 \mathrm{~mm})$; single glazed $(3 \mathrm{~mm})$ timber sash windows; timber door ( $45 \mathrm{~mm})$; and mineral wool roof insulation $(100 \mathrm{~mm})$.

- North facing building.

- The adjacent building is occupied so no heat flow through the eastern facade.

- $24 \mathrm{~h}$ occupancy profile used to gauge overall comfort levels.

- SAP heating profile (06:30 - 09:00 and 15:30 - 23:00 during the week; 06:30 - 23:00 at the weekend). 

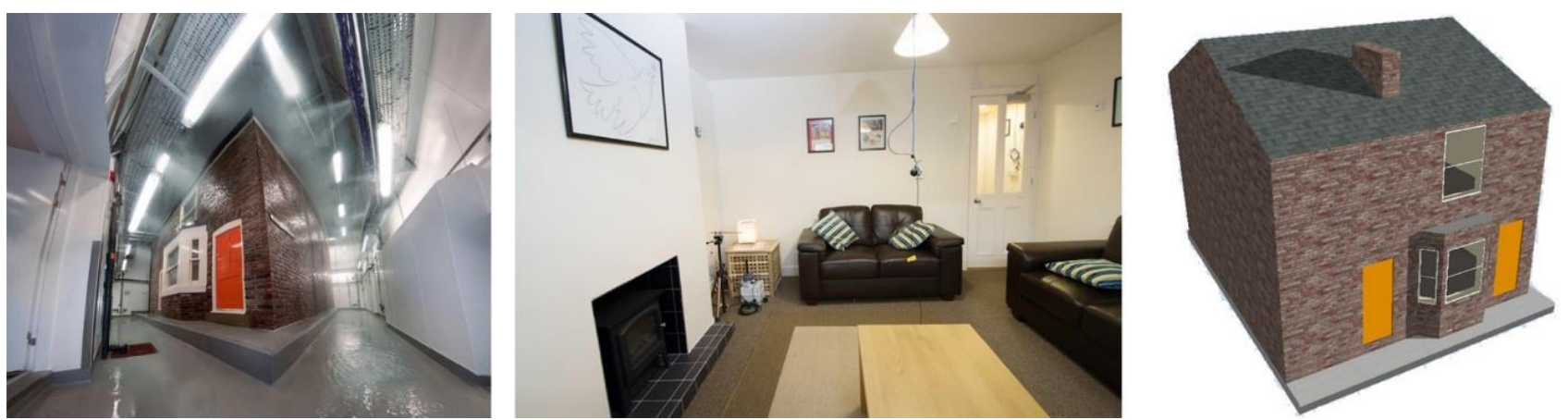

Figure 4: Left: The Energy House within the climate controlled chamber at the University of Salford. Middle: A view from the living room of the House. Right: The corresponding DesignBuilder model of the House.

To study the impact of greening the campus on indoor environment, the Energy House was simulated in DesignBuilder for $19^{\text {th }}$ of June 2017. Two simulations were carried out to show the impact of current land cover (Phase 2), and a greener land cover (Phase 3) on indoor thermal comfort, initial overheating, and the mitigation of overheating due to increased greenery of the Energy House. Therefore, first simulation was done with the weather dataset from ENVI-met outputs of Phase 2, and the second one was based on Phase 3.

For calculating the indoor thermal comfort, ASHRAE 55-2013 [44] was used. This standard has the largest database amongst other thermal comfort standards $[7,45,46]$. This standard measures comfort temperature with the following equation:

$T_{c o}=0.31 * T_{r e f}+17.8^{\circ} \mathrm{C}$

where $T_{c o}$ is comfort temperature, and $T_{\text {ref }}$ is prevailing mean outdoor air temperature. Based on the comfort temperatures, acceptability ranges for three categories of people are defined [47]:

- Category I, $90 \%$ of acceptability, with $\pm 2{ }^{\circ} \mathrm{C}$ deviation from the comfort temperature, for elderly and vulnerable users;

- Category $\mathrm{II}, 80 \%$ of acceptability, with $\pm 3{ }^{\circ} \mathrm{C}$ deviation from the comfort temperature, for normal expectations for new buildings; and

- Category III, $65 \%$ of acceptability, with $\pm 4{ }^{\circ} \mathrm{C}$ deviation from the comfort temperature, for moderate expectations for existing buildings.

In this paper, we used Category II with $80 \%$ of acceptability for the calculations of indoor thermal comfort of the house.

\subsection{Validation of ENVI-met results}

Several studies have validated ENVI-met results in different climates [48-50]. It should be noted that there are other computer models that predict different micrometeorological factors such as RayMan [51], SOLWEIG [52], and UMEP [53]. These models are very accurate in predicting mean radiant temperature in urban environments; however, compared to 
these approaches, ENVI-met offers the possibility of incorporating wind flow in the simulations, rendering it more appropriate for microclimate analysis.

To estimate the accuracy of ENVI-met results of this paper, two sets of air temperature results were compared. Three locations with different land covers were used for the validation procedure. Root mean square deviation (RMSD) was calculated between the measured and simulated air temperatures. To calculate the RMSD for the three locations, the following equation was used:

$R M S D=\sqrt{\frac{\sum_{1}^{n}(T s-T m)^{2}}{n}}$

Where Ts is ENVI-met simulated air temperature, and Tm is measured air temperature by data loggers.

To compare the measured versus simulated air temperatures, correlation coefficient and $\mathrm{R}^{2}$ were also calculated.

\section{Results}

\subsection{Measurements of local microclimates in summer 2017}

Air temperatures were measured in the city centre of Manchester, and in the campus of University of Salford from May to October 2017. Figure 5 shows the diurnal profile of air temperatures on $19^{\text {th }}$ June, which was the hottest day in that period. Due to the dependancy of the results to the accuracy of their data loggers $\left( \pm 0.2{ }^{\circ} \mathrm{C}\right.$ for the city centre, and $\pm 0.5^{\circ} \mathrm{C}$ for the university campus), the results are drawn by areas, instead of lines. As the figure shows, city centre was hotter than the university campus in the early morning (from midnight to 6:00 am, sunrise), in the early afternoon, and during the evening (due to the heat capacity of materials used in the city centre).

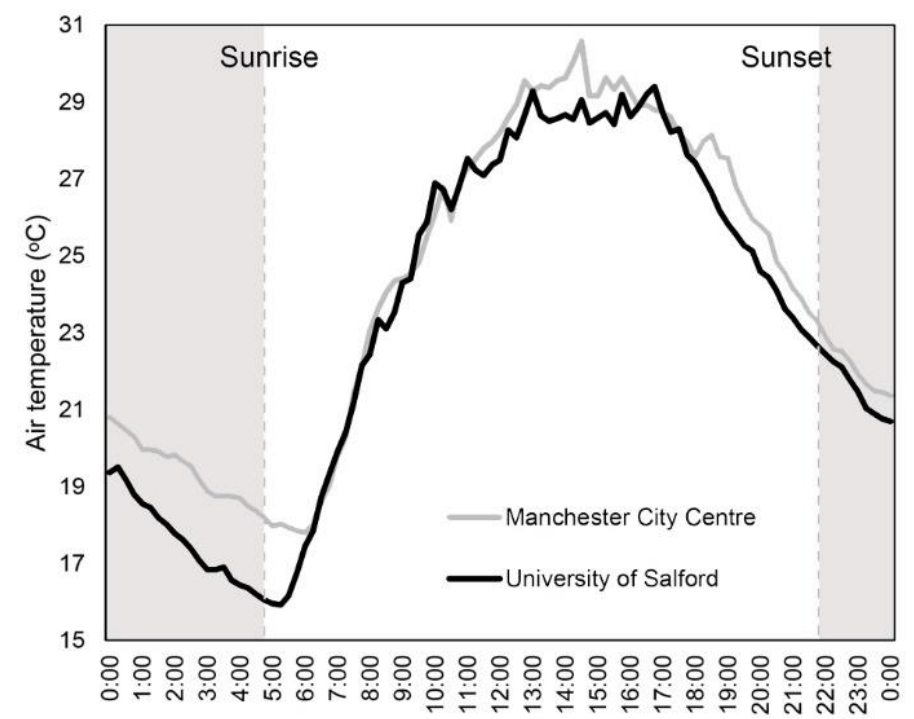

Figure 5: Diurnal profile of air temperatures measured in Manchester city centre and in the University of Salford, on $19^{\text {th }}$ of June 2017. 
Maximum air temperature in the city centre occurred at $14: 30$, and it was $1.2^{\circ} \mathrm{C}$ higher than the maximum temperature in the university campus. City centres have normally higher air temperatures due to the urban heat island effect [54]. Nevertheless, there is one other reason for this temperature difference in Figure 5. Part of the campus of the University of Salford is covered with vegetation (Peel Park), and there is a river (River Irwell) on the east side of the campus. These two natural elements can reduce local air temperatures [55-57].

Maximum UHI effect (temperature difference) was $2.3^{\circ} \mathrm{C}$ at $4: 00$. This is due to the fact that lowest temperatures normally occur around sunrise, when the absorbed heat is dissipated during the night. The minimum air temperature in the city centre is at $6: 00 \mathrm{am}\left(17.8^{\circ} \mathrm{C}\right)$, while the minimum air temperature in the campus occured at 5:00 am $\left(15.9^{\circ} \mathrm{C}\right)$. It should be noted that the air temepratures were recorded every 15 minutes. Hence, the city centre cooled down one hour later than the University. This could be due to the use of high heat capacity materials in the city centre (such as asphalt pavements). Furthermore, densly built environment in Manchester city centre can cause delay in dissipating heat during the night.

\subsection{Micrometeorological simulations and measurements within the campus}

Based on the recorded weather data in the campus of the University of Salford, micrometeorological simulations were done. This was to understand the thermal conditions within the campus during the hottest day of the year $\left(19^{\text {th }}\right.$ of June 2017). Figure 6 illustrates the air temperature distribution within the simulated domain, at the height of $1.2 \mathrm{~m}$ at 16:00. Air temperature varies from $23.9^{\circ} \mathrm{C}$ (in Peel Park) to $30.7^{\circ} \mathrm{C}$ (in the paved areas, on top-left of the domain).

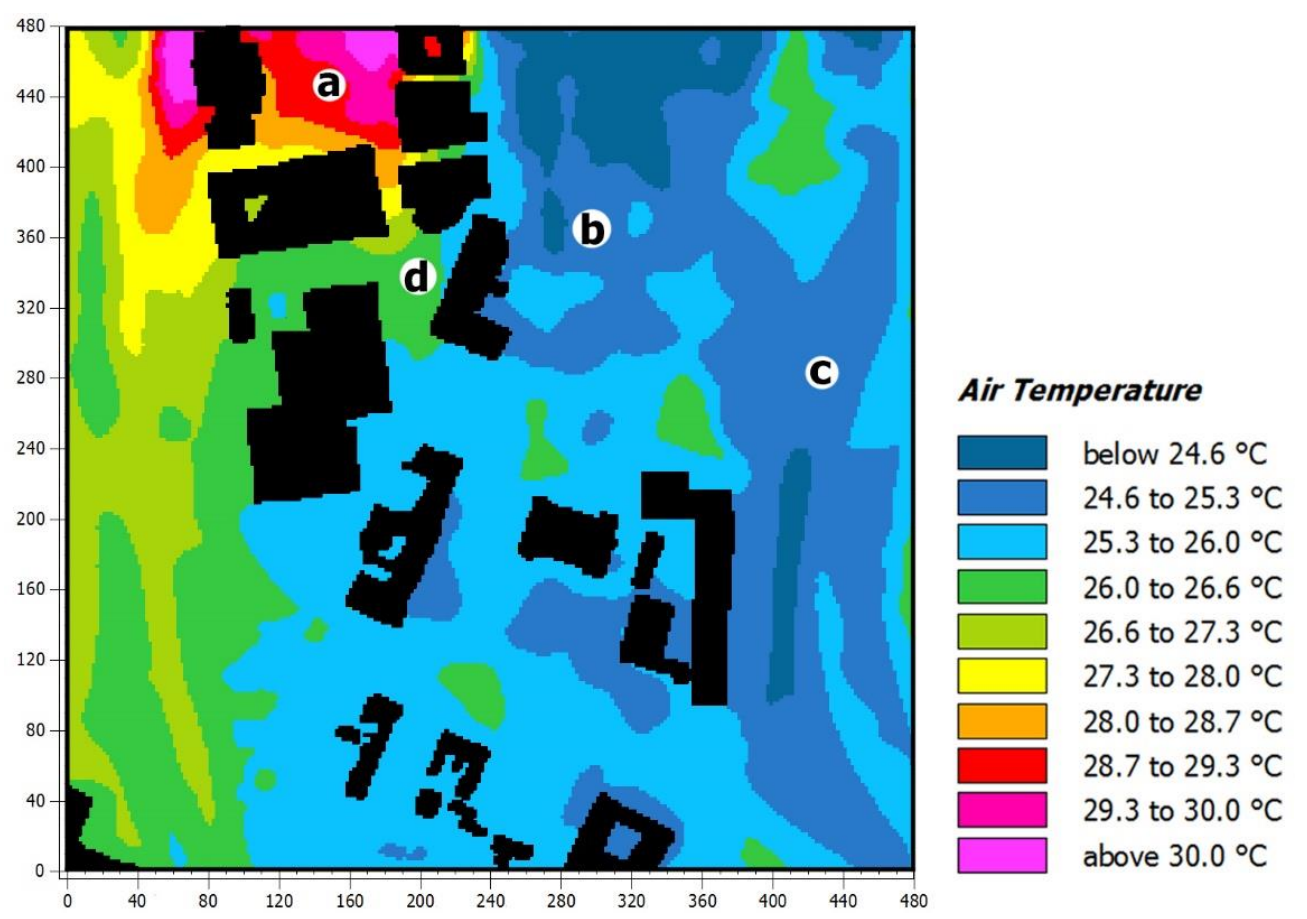

Figure 6: Distribution of air temperature within the campus of the University of Salford at 1.2 m, at 16:00. Point $a$ is a paved area with stone; Point $b$ is the campus park; Point $c$ is on River Irwell; and Point $d$ is also a parking lot paved with asphalt. 
Figure 7 shows thermal photos taken from different points with various land cover within the university campus. The location of these points are marked in Figure 6.

Point a in the campus is paved with granite stones. Stone is among high heat capacity materials, and can absorb heat during the day. Furthermore, this paved areas is unpermeable. Hence, evaporation from this area is reduced, which makes this area hotter than the other points. We included a grass area in the thermal photo to show the difference between the surface temperatures of the paved and grass area. The minimum surface temperature of the green area was $16.0^{\circ} \mathrm{C}$, while the nearby black stones were $26.2^{\circ} \mathrm{C}$. Due to the different albedos, white stones gained lower surface temperatures than the black ones.

Point $b$ in Figure 7 shows that the vegetated area have cooler surface temperatures compared to the building surfaces. The shaded area bellow the trees (covered with grass) has the least surface temperatures $\left(8.7^{\circ} \mathrm{C}\right.$ ), while the nearby black roof is $19.0^{\circ} \mathrm{C}$, and the facades facing to the south gained the highest surface temperatures $\left(26.8^{\circ} \mathrm{C}\right)$.

Point c in Figure 7 refers to River Irewell, which is located at the east side of the campus. The thermal photos shows the contrast between the residential buildings with black tile roofs at the east side of the campus and the river. Here the maximum surface temperature difference is $18.8^{\circ} \mathrm{C}$. 


\section{a) Paved area}

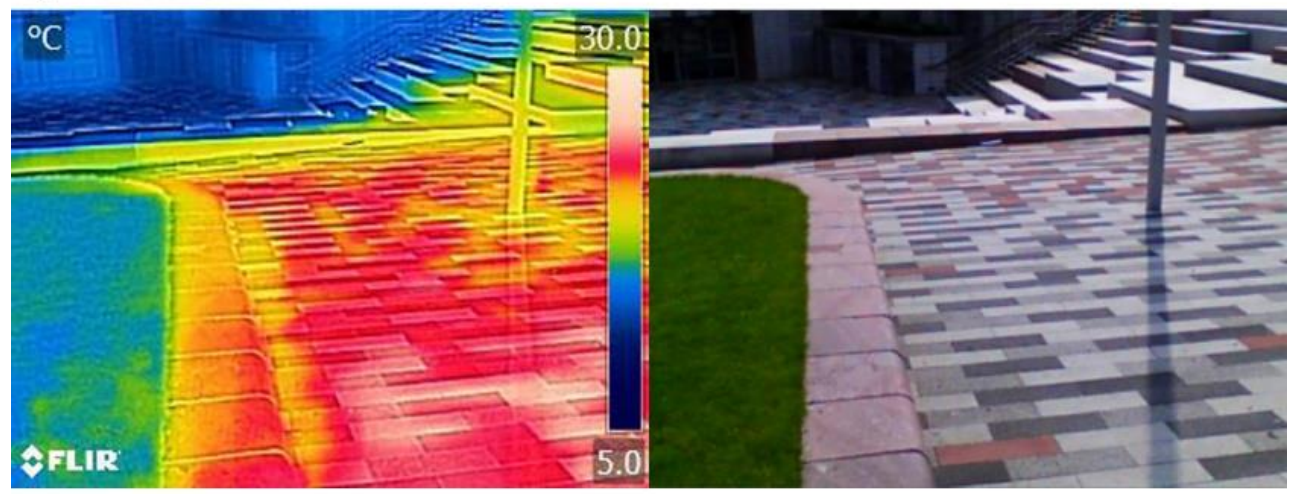

\section{b) Peel Park}

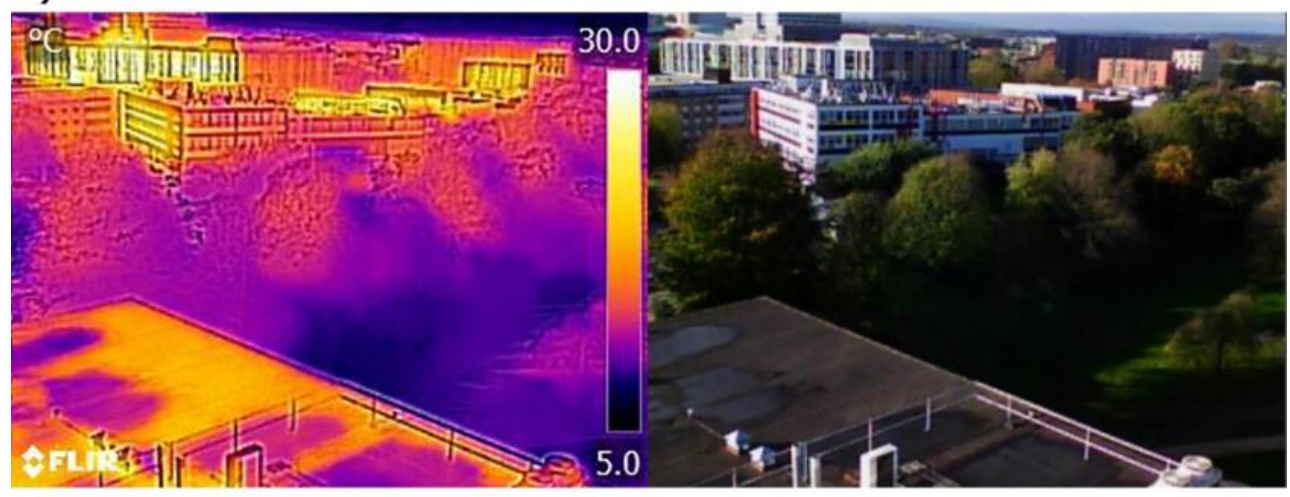

\section{c) River Irwell}

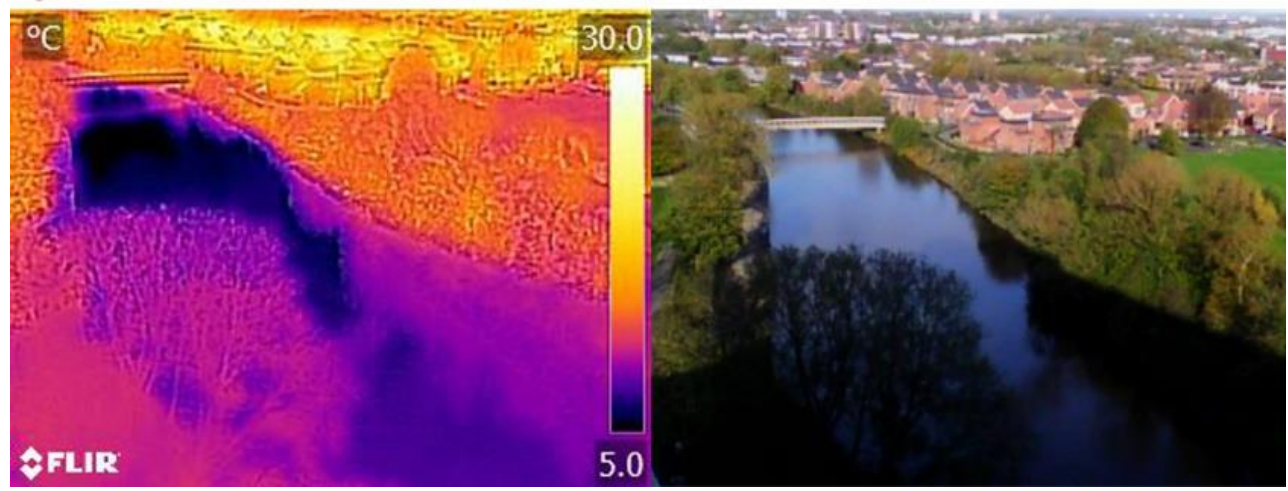

Figure 7: Thermal and corresponding visual photos of: a) the paved area, b) Peel Park, and c) River Irwell. The location of the points within the campus are marked in Figure 6.

Figure 8 illustrates the air temperatures recorded in point $b$ (Peel Park) and point $d$ ( $a$ parking lot paved with asphalt). Figure 8 top shows three days of measurements during a heat wave $\left(17^{\text {th }}\right.$ to $19^{\text {th }}$ of June 2017$)$. In these days, Peel Park was significantly cooler than the parking lot. On average, Peel Park was $1.1{ }^{\circ} \mathrm{C}$ cooler than the parking lot in these three days.

Figure 8 bottom shows the cooling impact of the park (parking lot temperatures minus park temperatures). The cooling impact has a similar pattern in these three days. Maximum cooling impacts happened from noon to early evening. This showed that the cooling impact of the park was during the hottest hours, with maximum $3.6^{\circ} \mathrm{C}$ at $14: 45$. In general, parks 
have higher cooling impacts during the day because of the evapotranspiration effect [1]. The evaporation of moisture from the soil and plant leaves in the park causes heat loss in that microclimate. This mechanism (causing maximum cooling effect) mostly happens during the day.
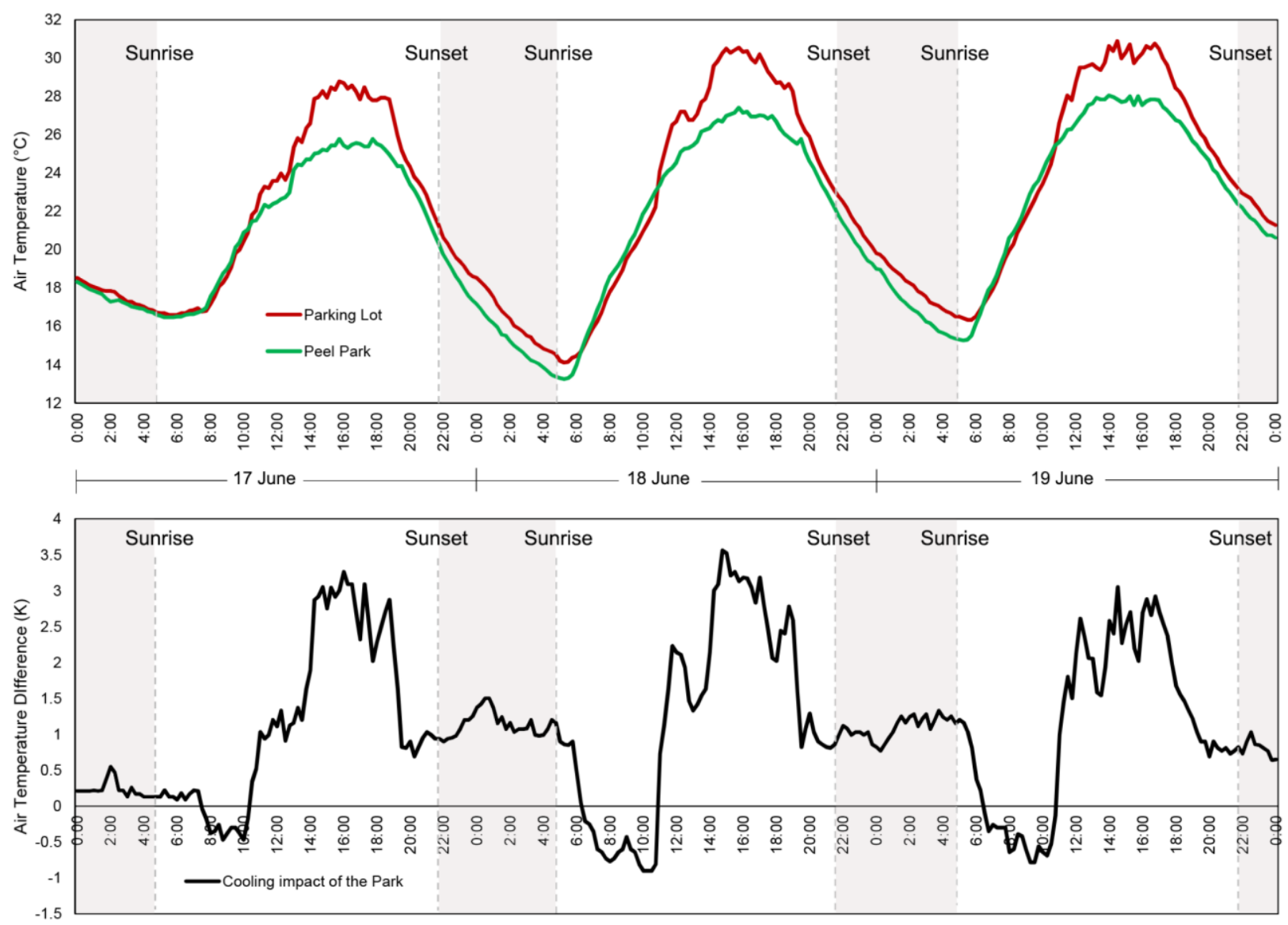

Figure 8: Top: Air temperatures measured in Peel Park (point b) and in a parking lot (point d). Bottom: The cooling impact of the park (parking lot temperatures minus park temperatures)

Several studies have shown the dangerous impacts of UHIs on vulnerable people during the nights [58-60]. Large cities cannot easily release their absorbed heat during the nights [54]. Figure 8 bottom shows that the park has still cooling effects during the nights. On average, the park is $0.9^{\circ} \mathrm{C}$ cooler than the parking lot during the nights (between sunsets and sunrises). However, the cooling impact drops everyday after sunrise untill 11:00. This could be because of the heat capacity of the materials used in the parking lot, as discussed in the introduction. It takes time for the asphalt pavement in the parking lot to asbrob heat. In general, the fluctuation of temperature in such materials is more than the vegetated environments. In this case, the maximum temperature variations in the parking lot was 16.2 ${ }^{\circ} \mathrm{C}$ (maximum $30.3^{\circ} \mathrm{C}$ at $16: 00-$ minimum $14.1^{\circ} \mathrm{C}$ at $5: 15$ ). This difference for the park was $14.1{ }^{\circ} \mathrm{C}$ (maximum $27.4^{\circ} \mathrm{C}$ at $16: 00$ - minimum $13.3^{\circ} \mathrm{C}$ at 5:30). 


\subsection{The impact of additional trees (as a renaturing scenario) on the microclimate of the campus}

As a heat mitigation strategy, extra trees were added to the campus through ENVI-met simulation. By this hypothetical scenario, the tree fraction was increased in the domain, from $21 \%$ in the control model to $38 \%$ in the additional trees scenario (physical domains are shown in Figure 3). The average air tempratures within the domains in each hour was calculated at the height of $1.2 \mathrm{~m}$. The results are shown in Figure 9. On average, the park cooled the domain up to $0.6^{\circ} \mathrm{C}$ on that day. Maximum cooling impact $\left(1.1^{\circ} \mathrm{C}\right)$ occurred at 16:00.

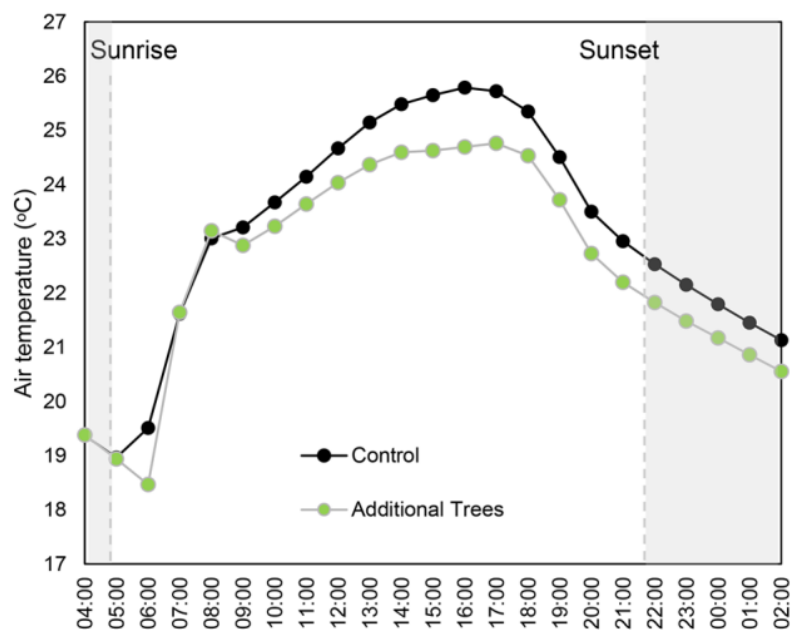

Figure 9: Average air temperatures within the whole domain cells (at 1.2m height) in the control scenario (current land cover), and when additional trees are added to the campus.

Figure 10 shows the cooling impact of new trees added to the campus (air temperature difference at 16:00). Maximum cooling impact was $3.8^{\circ} \mathrm{C}$ in north east, and north west of the campus (in dark blue). These two areas had grass, which were converted to trees. Average air temperature reduction within the whole domain was $1.1^{\circ} \mathrm{C}$. 


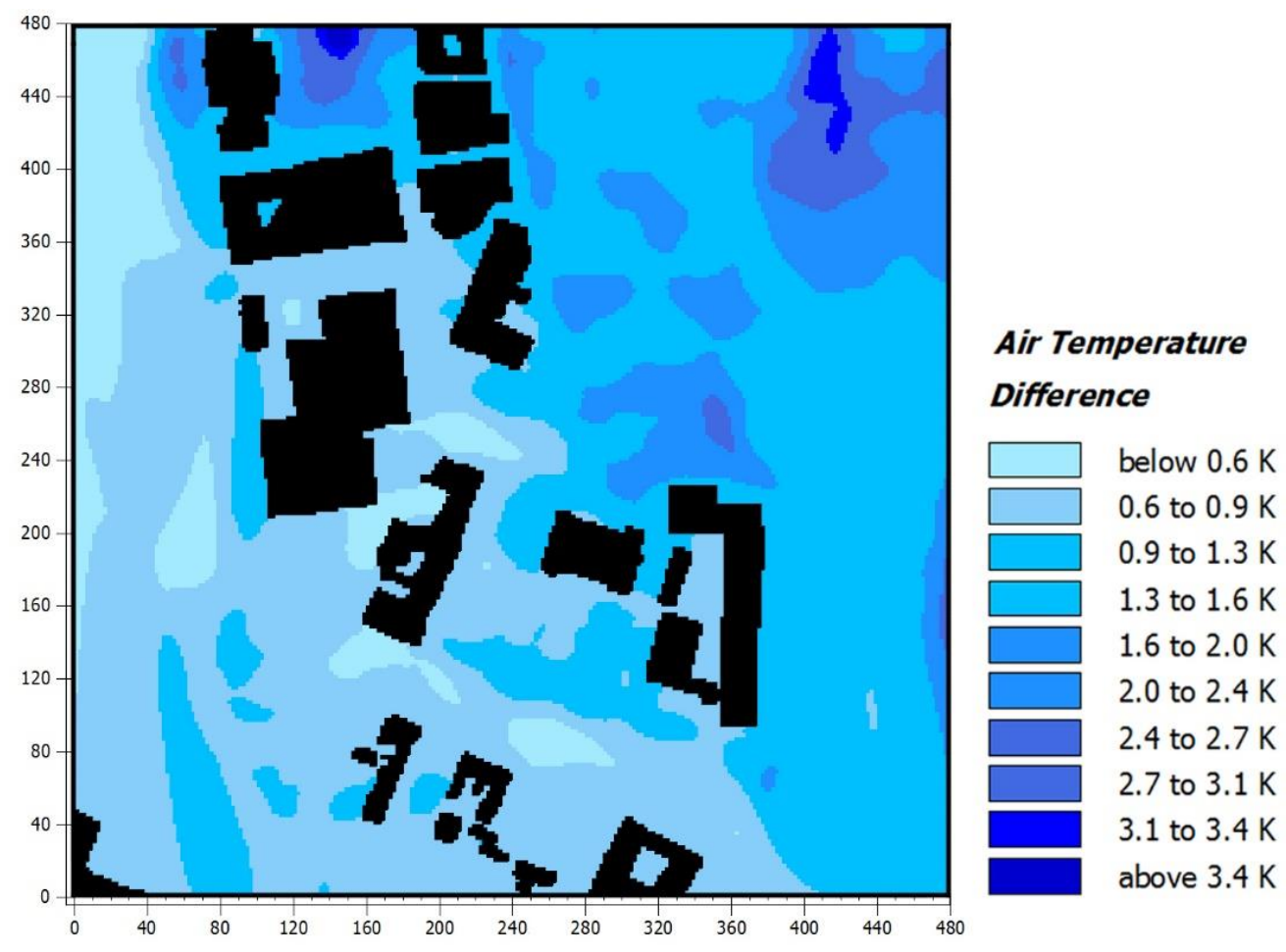

Figure 10: Air temperature difference when extra trees are added to the campus compared to the control simulation at $1.2 \mathrm{~m}$, at 16:00.

\subsection{Indoor thermal conditions modelling}

The local microclimate of the campus with its current land cover (Phase 2) and with additional trees (Phase 3 ) were simulated. The results generated two local weather data. The indoor thermal conditions of the Energy House was simulated with these two weather data (by using DesignBuilder).

Figure 11 top shows the indoor air temperature of the Energy House under the abovementioned scenarios, on $19^{\text {th }}$ of June 2017. Figure 11 bottom shows their temperature difference during the day. On average, Additional trees scenario reduced $2.9^{\circ} \mathrm{C}$ the indoor air temperature of the Energy House. There was one drop in cooling impact at 8:00 am, which was $2.2^{\circ} \mathrm{C}$.

Using ASHRAE 55 standard, indoor thermal comfort of the Energy House was calculated for these two scenarios. The results show that the Energy House was uncomfortably too hot during the 24 hours with the current land cover. Additional trees scenario reduced the number of discomfort hours to 19 hours. This means that indoor thermal comfort was improved by $20.8 \%$ during the hottest day of summer 2017. 

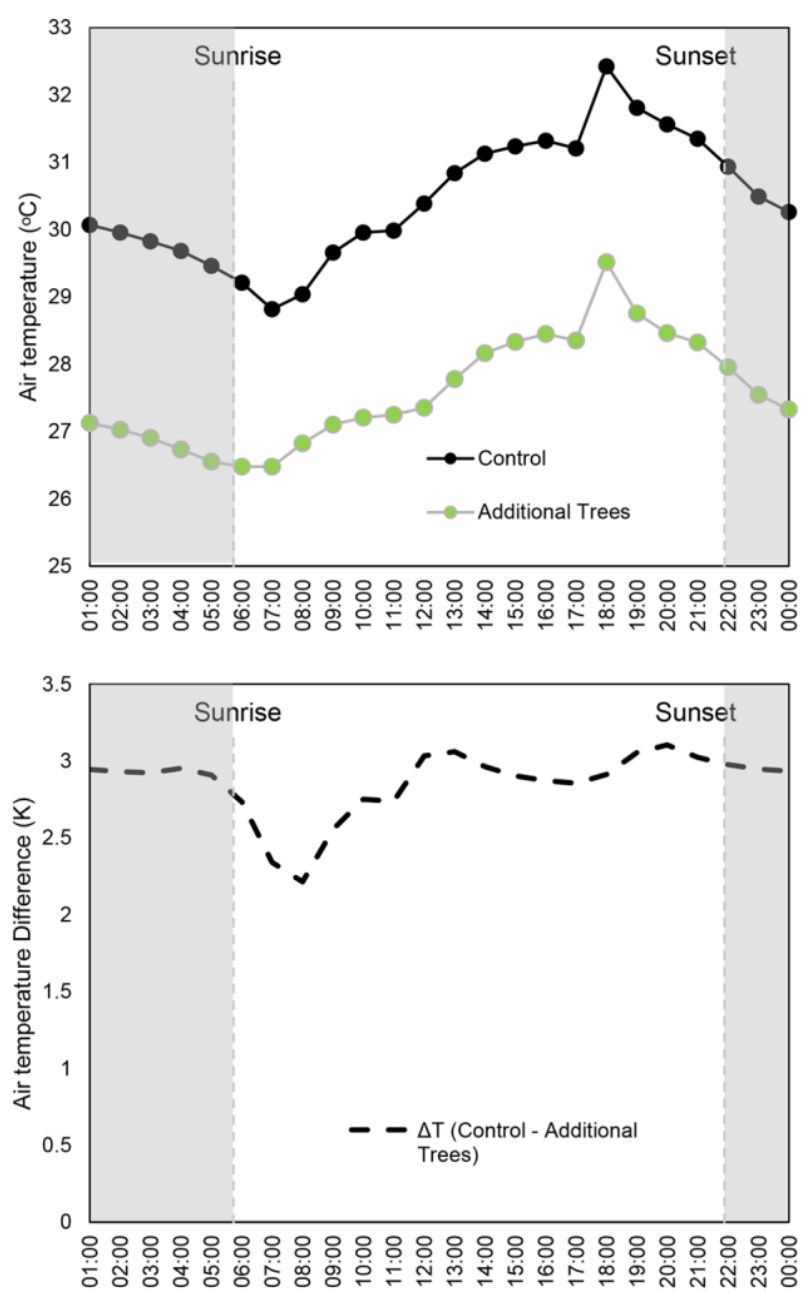

Figure 11: Top: Diurnal profile of indoor air temperatures of the Energy House under Control and Additional trees scenario. Bottom: Air temperature differences when trees are added to the campus.

\subsection{Validation of ENVI-met results}

This section reports on the validation of ENVI-met (as a CFD model) results. Figure 12 shows the diurnal (left panel) and scatterplot (right panel) graphs of the comparison between the measured and simulated air temperatures. The results belong to the parking lot of the Energy House. Measurement results were recorded by HOBO data loggers. Simulation results were taken from the ENVI-met receptor, at the exact location of the parking lot.

To compare the measurements versus simulations, RMSD was calculated for each location. The average $24 \mathrm{~h}$ RMSD for the Energy House was $2.9^{\circ} \mathrm{C}$. One main reason for this deviation could be the presence of cars in the parking lot. Cars could generate extra heat on top of the impact of the land cover. This was not possible to be included in ENVI-met. Correlation coefficient was also calculated to show the linear interdependence of the measured versus simulated results. The calculated correlation coefficient for these locations were 0.88 . 

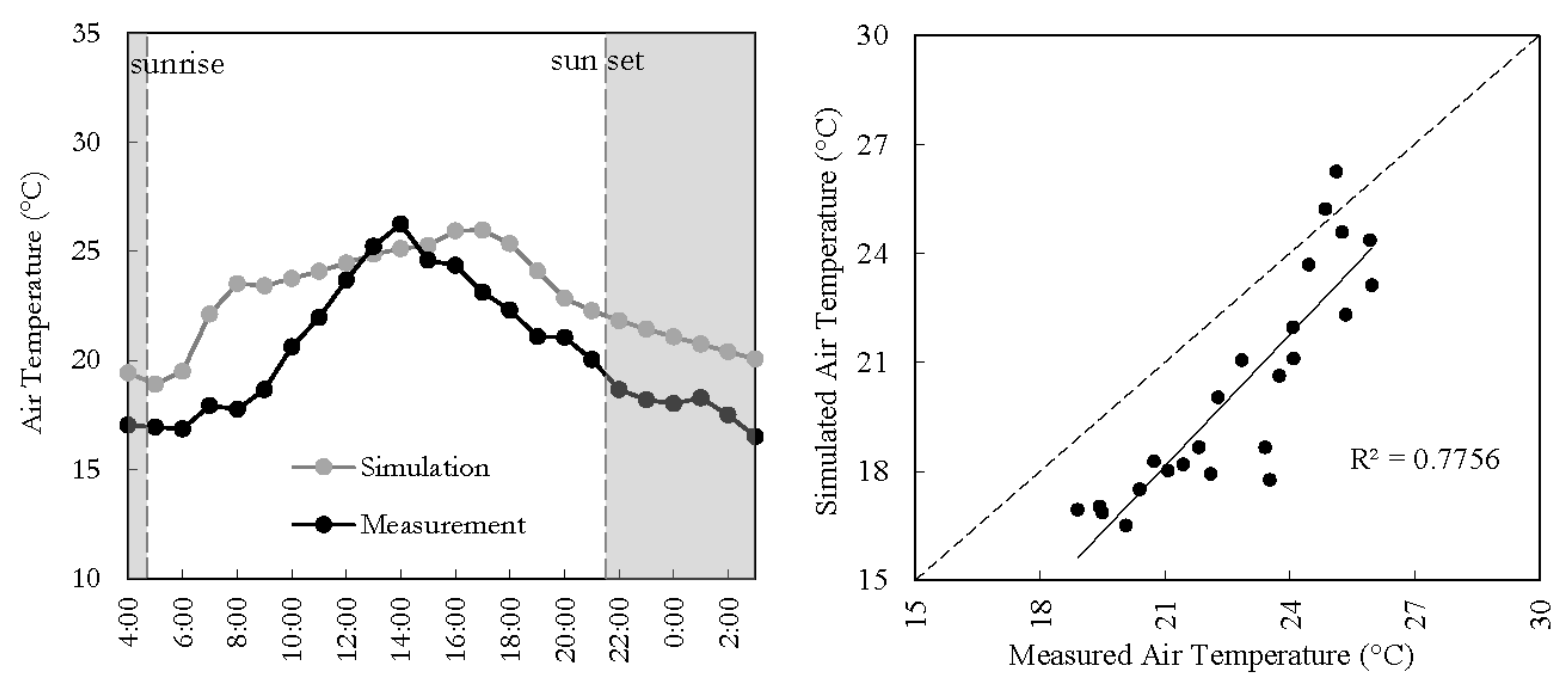

Figure 12: Comparison of ENVI-met simulation results with measurements in the Parking lot (Panel a); and the corresponding scatter plot (Panel b).

The abovementioned points are worth noting in any study that deals with CFD modelling for estimating temperature results.

\section{Summary and conclusions}

This paper investigated the impact of land cover on local microclimates, and consequently on indoor thermal comfort. Field measurements and computational modelling were carried out for a heat wave episode in Manchester. Through four phases, this study showed the direct impact of local land cover on thermal conditions:

In Phase 1, the UHI effect was studied between Manchester city centre and the campus of the University of Salford. It was found that during the hottest day of 2017, the maximum detected UHI was $2.3^{\circ} \mathrm{C}$ at $4: 00$. This was in accordance with most of the other UHI studies. This finding will help cities and urban planners make better decision considering the fact that buildings located in city centres will need higher night time cooling demand compared to rural areas.

In Phase 2, micrometeorological measurements and simulations were done on the campus of the University. It was found that air temperatures above the stoney paved area was 6.8 ${ }^{\circ} \mathrm{C}$ higher than the campus park. Maximum air temperatures in the paved areas occurred around 16:00, when materials with high heat capacity had absorbed heat during the day, and they start to release it back to the environment while the sun is still radiating to the environment. This finding would remind urban designers and architect to choose urban surfaces with more attention. Cities could also prepare their open spaces for heat waves by improving urban surfaces. 
In Phase 3, a hypothetical scenario with additional trees was simulated for the campus. The results showed that adding $17 \%$ more trees to the campus made it $1.1{ }^{\circ} \mathrm{C}$ cooler at the hottest hour of the day (at 16:00). Furthermore, it showed that the cooling impact is higher where more trees are added. This finding could be used for vulerable neighbourhoods where elderly (for example) live.

In Phase 4, indoor thermal comfort of the Energy House was studied during the hottest day of summer 2017. Two above scenarios were implemented to the Energy House (with current and greener land cover). It was found that adding more trees ( $17 \%$ more) to the campus increased the indoor thermal comfort of the Energy House by $20.8 \%$.

Finally, it should be said that adding trees to the university campus reduced the ambient air temperature, and consequently improved indoor thermal comfort of the Energy House. Selection of materials by designers or planners can significantly affect a microclimate. Improving indoor thermal comfort can reduce cooling energy demand in large cities like Manchester. Further research is needed to show how this energy reduction can diminish green house gas emissions around cities, and potentially improve air quality. Furthermore, the investigations done in this paper were focused on a summer heat wave. Energy demand and thermal comfort during winter times, and within different land covers are also of interest.

\section{Acknowledgement}

Authors would like to show their gratitude to Bruntwood in Manchester, Mr Victor Boys and Mr Adam Tillis for their support in Manchester city centre measurements.

Furthermore, we appreciate Mo Benjaber for his assistance in the field measurements within the campus of the University of Salford.

\section{References}

1. Oke, T.R., G. Mills, A. Christen, and J.A. Voogt, Urban Climates. 2017: Cambridge University Press.

2. Kleerekoper, L., M. van Esch, and T.B. Salcedo, How to make a city climate-proof, addressing the urban heat island effect. Resources, Conservation and Recycling, 2012. 64(0): p. 30-38.

3. Taleghani, M., Outdoor thermal comfort by different heat mitigation strategies- $A$ review. Renewable and Sustainable Energy Reviews, 2018. 81(Part 2): p. 2011-2018.

4. Yin, C., M. Yuan, Y. Lu, Y. Huang, and Y. Liu, Effects of urban form on the urban heat island effect based on spatial regression model. Science of The Total Environment, 2018. 634: p. 696-704. 
5. Chen, Y., X. Li, Y. Zheng, Y. Guan, and X. Liu, Estimating the relationship between urban forms and energy consumption: A case study in the Pearl River Delta, 20052008. Landscape and Urban Planning, 2011. 102(1): p. 33-42.

6. Akbari, H., L. Shea Rose, and H. Taha, Analyzing the land cover of an urban environment using high-resolution orthophotos. Landscape and Urban Planning, 2003. 63(1): p. 1-14.

7. Taleghani, M., Dwelling on Courtyards: Exploring the energy efficiency and comfort potential of courtyards for dwellings in the Netherlands. 2014, Delft University of Technology.

8. Middel, A., K. Häb, A.J. Brazel, C.A. Martin, and S. Guhathakurta, Impact of urban form and design on mid-afternoon microclimate in Phoenix Local Climate Zones. Landscape and Urban Planning, 2014. 122: p. 16-28.

9. Huang, K.-T., S.-R. Yang, A. Matzarakis, and T.-P. Lin, Identifying outdoor thermal risk areas and evaluation of future thermal comfort concerning shading orientation in a traditional settlement. Science of The Total Environment, 2018. 626: p. 567-580.

10. Kottek, M., J. Grieser, C. Beck, B. Rudolf, and F. Rubel, World Map of the KöppenGeiger climate classification updated. Meteorologische Zeitschrift, 2006. 15(3).

11. UKCP09. UKCP09: Gridded observation data sets. 2018 26.03.2018].

12. Manchester Strategy: A liveable and low carbon city. 2017 03.04.2018]; Available from:

http://www.manchester.gov.uk/info/200024/consultations and surveys/7004/man chester strategy a liveable and low carbon city/1.

13. Skelhorn, C.P., S. Lindley, and G. Levermore, Urban greening and the UHI: Seasonal trade-offs in heating and cooling energy consumption in Manchester, UK. Urban Climate, 2018. 23: p. 173-187.

14. Levermore, G., J. Parkinson, K. Lee, P. Laycock, and S. Lindley, The increasing trend of the urban heat island intensity. Urban Climate, 2017.

15. Skelhorn, C.P., G. Levermore, and S.J. Lindley, Impacts on cooling energy consumption due to the UHI and vegetation changes in Manchester, UK. Energy and Buildings, 2016. 122: p. 150-159.

16. Taha, H., Cool Cities: Counteracting Potential Climate Change and its Health Impacts. Current Climate Change Reports, 2015. 1(3): p. 163-175.

17. Kleerekoper, L., M. Taleghani, A. van den Dobbelsteen, and T. Hordijk, Urban measures for hot weather conditions in a temperate climate condition: A review study. Renewable and Sustainable Energy Reviews, 2017. 75: p. 515-533.

18. Lanza, K. and B. Stone, Climate adaptation in cities: What trees are suitable for urban heat management? Landscape and Urban Planning, 2016. 153: p. 74-82.

19. Tiwary, A. and P. Kumar, Impact evaluation of green-grey infrastructure interaction on built-space integrity: An emerging perspective to urban ecosystem service. Science of The Total Environment, 2014. 487: p. 350-360.

20. Santamouris, M., Cooling the cities - A review of reflective and green roof mitigation technologies to fight heat island and improve comfort in urban environments. Solar Energy, 2014. 103: p. 682-703.

21. Shojaei, P., et al., Effect of different land cover/use types on canopy layer air temperature in an urban area with a dry climate. Building and Environment, 2017. 125: p. 451-463. 
22. Taleghani, M. and U. Berardi, The effect of pavement characteristics on pedestrians' thermal comfort in Toronto. Urban Climate, Under review.

23. Doulos, L., M. Santamouris, and I. Livada, Passive cooling of outdoor urban spaces. The role of materials. Solar Energy, 2004. 77(2): p. 231-249.

24. Hwang, Y.H., Q.J.G. Lum, and Y.K.D. Chan, Micro-scale thermal performance of tropical urban parks in Singapore. Building and Environment, 2015. 94, Part 2: p. 467-476.

25. Coccolo, S., Bioclimatic Design of Sustainable Campuses using Advanced Optimisation Methods. EPFL.

26. Kolokotsa, D., M. Santamouris, and S.C. Zerefos, Green and cool roofs' urban heat island mitigation potential in European climates for office buildings under free floating conditions. Solar Energy, 2013. 95: p. 118-130.

27. Yang, J., et al., Green and cool roofs' urban heat island mitigation potential in tropical climate. Solar Energy, 2018. 173: p. 597-609.

28. Campbell-Scientific. MP100A Temperature and Relative Humidity Probe. 2018 29.03.2018]; Available from:

ftp://ftp.campbellsci.co.uk/pub/csl/outgoing/uk/leaflets/mp100a mar09.pdf.

29. ONSET. HOBO MX2305 Temperature Data Logger. 2018 29.03.2018]; Available from: http://www.onsetcomp.com/products/data-loggers/m×2305.

30. Bruse, M. ENVI-met website. 2019; Available from: http://www.envimet.com.

31. Bruse, M., ENVI-met 3.0: Updated Model Overview. 2004.

32. Bruse, M. Simulating microscale climate interactions in complex terrain with a highresolution numerical model: A case study for the Sydney CBD Area. in Biometeorology and Urban Climatology at the Turn of the Millennium, WMO/TD No. 1026. 2000. World Meteorological Organisation, Geneva, $\mathrm{CH}$.

33. Launder, B.E. and D.B. Spalding, The numerical computation of turbulent flows. Computer Methods in Applied Mechanics and Engineering, 1974. 3(2): p. 269-289.

34. Jiang, C., Improving Urban Climate Data Collection: Assessment and Redesign of Tsinghua's Meteorological Sensor Network. 2017, Princeton University.

35. FLIR. FLIR Tools Software. 2017 09.03.2018]; Available from: http://www1.flir.com/l/5392/2011-06-08/IUUE.

36. Energy-House. 2018 06.03.2018]; Available from: https://www.salford.ac.uk/builtenvironment/laboratories-and-studios/energy-house.

37. Energy-House, Salford Energy House: An overview. 2018.

38. DesignBuilder. 2017; Available from: http://www.designbuilder.co.uk.

39. EnergyPlus, EnergyPlus Development Team. Input output reference: the encyclopedic reference to EnergyPlus input and output. EnergyPlus 2010; version 6.0. 2010.

40. Marshall, A., et al., Domestic building fabric performance: Closing the gap between the in situ measured and modelled performance. Energy and Buildings, 2017. 150: p. 307-317.

41. ISO-9869, Thermal insulation - Building elements - In situ measurement of thermal resistance and thermal transmittance. 1994: Geneva, Switzerland, International Organization for Standardisation.

42. ATTMA, ATTMA Technical Standard L1. Measuring the Air Permeability of Building Envelopes (Dwellings), in October 2010 Issue. 2010: Northampton, UK, Air Tightness Testing and Measurement Association. 
43. Farmer, D., et al., Measuring thermal performance in steady-state conditions at each stage of a full fabric retrofit to a solid wall dwelling. Energy and Buildings, 2017. 156: p. 404-414.

44. ASHRAE, ASHRAE Standard 55-2013 in Thermal Environmental Conditions for Human Occupancy. 2013, ASHRAE Atlanta, GA.

45. deDear, R.J. and G.S. Brager, Thermal comfort in naturally ventilated buildings: revisions to ASHRAE Standard 55. Energy and Buildings, 2002. 34(6): p. 549-561.

46. Nicol, J.F. and M.A. Humphreys, Adaptive thermal comfort and sustainable thermal standards for buildings. Energy and Buildings, 2002. 34(6): p. 563-572.

47. CEN, C.E.e.d.N., CEN Standard EN 15251, in Indoor Environmental Input Parameters for Design and Assessment of Energy Performance of Buildings Addressing Indoor Air Quality, Thermal Environment, Lighting and Acoustics. 2007, CEN: Brussels.

48. Dain Jeong, et al., Validation of ENVI-met PMV values by in-situ measurements, in ICUC9 9th International Conference on Urban Climate jointly with 12th Symposium on the Urban Environment. 2015: Toulouse, France.

49. Elnabawi, M.H., N. Hamza, and S. Dudek, Numerical modelling evaluation for the microclimate of an outdoor urban form in Cairo, Egypt. HBRC Journal, 2015. 11(2): p. 246-251.

50. Taleghani, M., M. Tenpierik, A. van den Dobbelsteen, and D.J. Sailor, Heat in courtyards: A validated and calibrated parametric study of heat mitigation strategies for urban courtyards in the Netherlands. Solar Energy, 2014. 103: p. 108-124.

51. Matzarakis, A., F. Rutz, and H. Mayer, Modelling radiation fluxes in simple and complex environments - application of the RayMan model. International Journal of Biometeorology, 2007. 51(4): p. 323-334.

52. Lindberg, F., B. Holmer, and S. Thorsson, SOLWEIG 1.0-Modelling spatial variations of $3 D$ radiant fluxes and mean radiant temperature in complex urban settings. International Journal of Biometeorology, 2008. 52(7): p. 697-713.

53. Lindberg, F., et al., Urban Multi-scale Environmental Predictor (UMEP): An integrated tool for city-based climate services. Environmental Modelling \& Software, 2018. 99: p. 70-87.

54. Hart, M. and D. Sailor, Quantifying the influence of land-use and surface characteristics on spatial variability in the urban heat island. Theoretical and Applied Climatology, 2009. 95(3-4): p. 397-406.

55. Oke, T.R., Boundary Layer Climates. 2002: Taylor \& Francis.

56. Taleghani, M., The impact of increasing urban surface albedo on outdoor summer thermal comfort within a university campus. Urban Climate, 2018. 24: p. 175-184.

57. Yang, A.-S., Y.-H. Juan, C.-Y. Wen, and C.-J. Chang, Numerical simulation of cooling effect of vegetation enhancement in a subtropical urban park. Applied Energy, 2017. 192: p. 178-200.

58. Kalkstein, L., S. Greene, D. Mills, and J. Samenow, An evaluation of the progress in reducing heat-related human mortality in major U.S. cities. Natural Hazards, 2011. 56(1): p. 113-129.

59. Klein Rosenthal, J., P.L. Kinney, and K.B. Metzger, Intra-urban vulnerability to heatrelated mortality in New York City, 1997-2006. Health \& Place, 2014. 30: p. 45-60.

60. Ruiz, M.A., M.B. Sosa, E.N. Correa, and M.A. Cantón, Design tool to improve daytime thermal comfort and nighttime cooling of urban canyons. Landscape and Urban Planning, 2017. 167: p. 249-256. 
